\title{
John Harrison: A Case Study of the Acculturation of an Early Modern Briton
}

\author{
Rickie Lette*
}

\begin{abstract}
The important role that the Mediterranean played in England's development as an imperial power in the early modern period has begun to be appreciated, but more work is required to properly historicize the interactions which occurred during this time and understand their impact. This article argues that to do this it is necessary to move beyond generalized interpretations and examine the impact of encounter at the individual level. Moreover, through examining the experiences of one such sojourner, it demonstrates how a focus on acculturative change can provide novel insights into the consequences of historical encounters between European and non-European peoples.
\end{abstract}

The Mediterranean has long been sidelined in the narrative of British commercial and political expansion. But over the past two decades the sea has once again began attracting the attention of scholars, who are not only affirming the continuity of its historical importance as a meeting place for competing states and cultures, and a centre for trade and commerce, but also the significant contribution it made to British culture, national identity, and imperial development during the early modern period. ${ }^{1}$ Understanding the experience of Britons in the Mediterranean is important, not only in terms of illuminating Britain's naval, political, and economic history, but also to understanding the nation's social and cultural development. More generally though, as one scholar has observed, the Mediterranean provides an 'excellent laboratory' in which to explore the issues of identity, cultures, and the interaction of individuals and groups under conditions of both peace and conflict. ${ }^{2}$

However, among the first to reappraise the role of the Mediterranean in the shaping of British history were not cultural historians but rather literary scholars examining how depictions of Muslims in early modern English plays and literature

* This article is based on the author's research for his doctoral thesis, which was supported by an Australian Government Research Training Program Scholarship.

1 Linda Colley, Captives: Britain, Empire, and the World, 1600-1850 (New York: Anchor Books, 2004), pp. 33-35; Nabil Matar, Britain and Barbary, 1589-1689 (Gainesville: University Press of Florida, 2006), p. ix; Tristan M. Stein, 'The Mediterranean in the English Empire of Trade, 1660-1678' (unpublished doctoral dissertation, Harvard University, 2012), pp. 8,13 .

2 Eric R. Dursteler, Venetians in Constantinople: Nation, Identity, and Coexistence in the Early Modern Mediterranean (Baltimore: Johns Hopkins University Press, 2006), p. 2. Dursteler notes that while much of the important earlier work on the encounter of Europeans with other cultures has been situated in Asia, Africa, and the Americas, attention is now being given to the Mediterranean. 
reflected contemporary understanding of ethnic and racial difference. Much of this work is post-colonial in nature, informed by Edward Said's conception of a Western Orientalist discourse, and attempts to establish a connection between the construction of the cultural and ethnic Other and processes of conquest and empire building. ${ }^{3}$ Preoccupation with Saidian notions of power and hegemony, and of associated colonial and imperial discourses continue to inform the methodologies of studies of the contact of Britons with the region in the early modern period.

Literary scholars have also been influential in drawing attention to another aspect of the early modern Mediterranean which has, arguably, wider historical significance, and that is the phenomenon of Christian European captivity and enslavement by Muslim privateers - more generally referred to as 'corsairs' in the context of the Mediterranean - operating from the coast of North Africa between the sixteenth and nineteenth centuries. Accounts left by the victims-socalled Barbary captivity narratives ${ }^{4}$ — provide a rich, but at times interpretively problematic, source of historic detail derived from the author's or the narrator's intimate, often traumatic, engagement with Barbary. However, captivity narratives do reinforce the fact that for many Europeans Barbary was more than an imaginative construct, it was a lived reality, often involuntary, and experienced in a multiplicity of ways. ${ }^{5}$

While relations between Christian Europe and the Islamicate ${ }^{6}$ societies of North Africa during the early modern period have began to attract increasing

3 Nabil Matar, Turks, Moors and Englishmen in the Age of Discovery (New York: Columbia University Press, 1999), pp. 8-12. A. G. Hopkins comments on the general 'mass conversion of newcomers from literary studies' to colonial studies that occurred as a result of the influence of post-modernism. See Hopkins, 'Development of the Utopian Ideal, 1960-1999', in The Oxford History of the British Empire, ed. by Wm. Roger Louis and others, 5 vols (Oxford: Oxford University Press, 1998-99), v: Historiography, ed. by Robin W. Winks (1999), pp. 63852 (p. 648).

4 'Barbary' was adopted by early modern Britons to denote the area which roughly encompasses the modern-day states of Libya, Tunisia, Algeria, and Morocco, whose peoples share similar ethno-linguistic identity, cultural traditions and religious institutions. It was traditionally known to Arabs as the Maghrib (or Maghreb), the 'Land of Sunset'. See Jamil M. Abun-Nasr, A History of the Maghrib in the Islamic Period (Cambridge: Cambridge University Press, 1987), pp. 1, 4; Matar, Britain and Barbary, p. 3. Scholars commonly use Barbary and North Africa as generally synonymous toponyms. While this is not strictly incorrect, as there is no single accepted definition, both Egypt and Sudan are now commonly considered to be part of North Africa. The area generally associated with Barbary could more precisely be referred to as Northwest Africa, but in the interests of consistency with the general literature it is referred to as North Africa in this article.

5 Robert C. Davis has estimated that at least one million people were captured from vessels and coastal areas of the Mediterranean, the British Isles, and as far north as Iceland between 1530 and 1780 . However, it has been argued that these figures are excessive, and even Davis is circumspect about the reliability of the sources on which they are based. See Davis, 'Counting European Slaves on the Barbary Coast', Past \& Present, 172.1 (2001), 87-124 (pp. 96-97, 118); Nabil Matar, British Captives from the Mediterranean to the Atlantic, 15631760 (Leiden: Brill, 2014), pp. 9-11.

6 As with 'Islamdom', the historian Marshall G. S. Hodgson coined this term to overcome the general tendency toward casual conflation of the religion with the social structures and cultural traditions with which it has been historically associated. He thus restricted 'the term 
interest from scholars, there remains much work to be done to properly historicize the interactions of this period, and understand their impact. In this respect, there is a fundamental question that remains to be satisfactorily addressed concerning the activities of Britons in North Africa during the seventeenth century, and that concerns the effect that their encounters with this part of the world actually had on the development of British self-identity, and, by extension, Britain's imperial progression.

The challenge for anyone seeking to answer this question is to establish a clear relationship between cause and effect: to distinguish the particular influence that experience in North Africa may have had on shaping the worldview of early modern Britons and nurturing imperial and colonial aspiration from the many and varied other factors which undoubtedly contributed to this development. For this reason, in a departure from previous work on the subject, notably by Linda Colley and Nabil Matar, ${ }^{7}$ the focus of my recent research has not been on generalized interpretations, but rather on elucidating a deeper understanding of the impact of encounter at the individual level among Britons who had actual lived experience in that part of North Africa in which they had the most consistent, and broadest range of, relations during the early modern period, Morocco. ${ }^{8}$

This work has been based on close, contextualized, 'against-the-grain' (re) readings of contemporary sources informed by the principles of psychological acculturation and notions concerning the influence of inter-cultural engagement more generally on individual learning and behaviour, and wider cultural and social development. ${ }^{9}$ By doing so, I have sought to identify not only the affective,

"Islam" to the religion of the Muslims, not using that term for the far more general phenomena, the society of Islamdom and its Islamicate cultural traditions'. See Hodgson, The Venture of Islam, 3 vols (Chicago: University of Chicago Press, 1977), I: The Classical Age of Islam, pp. 58-59.

7 Matar has been prolific in his studies of relations between early modern Britain, Western Europe, and the Islamicate states of the Mediterranean, with his book Britain and Barbary of particular relevance to this article, and Linda Colley has provided other novel insights through her use of the experiences of Britons held in captivity to reappraise the rise of the British Empire in Captives.

8 While Morocco has coasts bordering both the Atlantic Ocean and the Mediterranean Sea, during the early modern period much of what is now modern-day Morocco was conceived of as being part of a geographic and imaginative construct called Barbary which was centred on the Mediterranean, not the Atlantic.

9 There is no generally accepted definition of acculturation, but, broadly, it encompasses the changes - psychological, social, and cultural — which result when individuals from one culture come into contact with another. Space precludes the inclusion of a meaningful discussion of cross-cultural psychology and the generally well accepted model for examining psychological acculturative change and cultural adaptation experienced by individuals, the ABC model of culture shock, which has informed my general approach to analysis of responses in my doctoral research. On the former, see John W. Berry and others, Cross-Cultural Psychology: Research and Applications, 3rd edn (New York: Cambridge University Press, 2012), esp. pp. 1-4, 324. On the latter, see Colleen Ward, Stephen Bochner, and Adrian Furnham, The Psychology of Culture Shock, 2nd edn (Hove: Routledge, 2001), esp. pp. 1, 4-5, 80-82, 270-74; Berry and others, Cross-Cultural Psychology, pp. 314-15; H. Chad Lane, 'Intercultural Learning', in Encyclopedia of the Sciences of Learning, ed. by N. M. Seel (New York: Springer, 2012), p. 1619. 
cognitive, and behavioural responses of sojourners to Morocco, but also the personal and other proximate factors which influenced those responses, and assess the impact that their experiences had on them, and in shaping Anglo-Moroccan trade and diplomatic relations more generally. In this article, I apply this broad methodological framework to examine one particularly interesting subject, John Harrison $($ d. $1641 \times 52$ ), whose story not only reveals the role that religious conviction and ideological belief could play in personal acculturation, but also demonstrates how a focus on the processes of acculturative change can provide novel, more nuanced insights into the consequences of historical encounters between European and non-European peoples.

Harrison's extensive experience as a political agent in Morocco, acquired over the course of eight missions he conducted between 1610 and 1632, provided him with what appears to have been a sound knowledge of the country's history, society, culture, religious practices, and political structures. One scholar has gone as far as describing him as having 'laid the foundations for England's commercial and ideological relations with Morocco', ${ }^{10}$ but this claim cannot be substantiated based on the available evidence. England's commercial relationship with Morocco was already well established by the time Harrison appeared, and there is little proof of him having had a direct, long-term impact on shaping either English geopolitical or commercial thinking about the region. Nevertheless he was, for a time, highly regarded, and an important figure in Anglo-Moroccan relations in the first third of the seventeenth century, and his life and writings about Morocco warrant more attention than they have been given by historians. He is an excellent subject for a study of the present kind because of the extended period over which he worked in Morocco, the breadth of his experiences there, and the detailed accounts and other works that he left.

There is little currently known about Harrison's early life. He appears to have served in the English army in Ireland under Elizabeth I, and upon the accession of James I Harrison was appointed to the privy chamber of the king's son, Prince Henry, remaining in that position until Henry's death in 1612. He then joined the retinue of James's daughter Elizabeth, the Countess Palatine of the Rhine, until at least 1619, and was later appointed sheriff, or governor, of the Somers Isles (Bermuda), before he once again returned to Morocco. ${ }^{11}$ The following discussion contributes to the limited information currently available on this intriquing figure.

\section{Muslim Pirates and English Captives, 1610-16}

The Sa dian dynasty was established in Morocco in the mid-1500s around the same time as England's trading relations with the country were quickly developing. Despite their professed aim of ridding Morocco of Christian Europeans, or at

10 Nabil Matar, 'Harrison, John (d. $1641 \times 52)$ ', in Oxford Dictionary of National Biography Online <http://www.oxforddnb.com/view/article/12435> [accessed 12 July 2017].

11 Dictionary of National Biography, ed. by Leslie Stephen and Sidney Lee, 63 vols (London: Smith, Elder, 1885-1900), XXV (1891), p. 33, s.v. 'Harrison, John ( $f$. 1630)'; Matar, 'Harrison, John'. 
least depriving them of independent activity in the country, the Sa ${ }^{e}$ dis adopted a pragmatic foreign policy, using trade and shrewd management of relations with the European powers to confront both internal and external forces seeking to usurp them. Under Elizabeth I and the Sa ${ }^{e}$ ī sultan Mawlāy Ahmad al-Mansūr, England and Morocco had enjoyed a long period of close commercial and political relations which had been supported by shared concerns about Spain. ${ }^{12}$ However, with the death of both rulers in 1603, the situation changed as Morocco slid into internecine conflict and England politically disengaged with the country following the accession of James I. With the loss of a strong central government, corsairs operating from Salé on the Atlantic coast took advantage of the situation, quickly becoming a source of tension between the two countries, not only due to the disruption of English shipping and trade resulting from their predations, but also increasingly in response to the capture of crews and passengers, who were either held for ransom or sold into captivity; although, notably, it was the grievances of English merchants and not the plight of his subjects that first forced James to send an envoy to resolve the situation. ${ }^{13}$

Complaints from Morocco had started being received in London very soon after al-Mansūr's death, expressing concern about the behaviour of the late sultan's son, Abu Faris (r. 1603-09), who controlled Marrakesh. It was claimed that Abu Faris had reneged on commitments negotiated by the English with his father, and that he was not protecting the interests of the English trading community. ${ }^{14}$ Harrison was dispatched and arrived in Morocco in June 1610 to deliver a letter from the king to Mawlāy Zaydān, who, having defeated his brother, now ruled Marrakesh as well as the territory of Sus to the south. After a long delay Harrison was finally invited to present the details of the grievances, but Zaydān refuted the claims, advising Harrison that the merchants had breached the laws of his country. Consequently, he would not compensate them, but he did confirm the maintenance

12 On the rise of the Sa'dīs, see, for example, R. Mantran, 'North Africa in the Sixteenth and Seventeenth Centuries', in The Cambridge History of Islam, ed. by P. M. Holt, Anne K. S. Lambton, and Bernard Lewis, 2 vols (Cambridge: Cambridge University Press, 1970), II: The Further Islamic Lands, Islamic Society and Civilization, pp. 240-47; Charles-André Julien, The History of North Africa: Tunisia, Algeria, Morocco: From the Arab Conquest to 1830, trans. by John Petrie, ed. by C. C. Stewart (London: Routledge \& Kegan Paul, 1970), pp. 213-36; Abun-Nasr, A History of the Maghrib, pp. 210-18. The dynasty reached its zenith in power and ambition under Mawlāy al-Mansūr, on which see in particular Mercedes García-Arenal, Ahmad al-Mansur: The Beginnings of Modern Morocco (London: One World, 2009); and Stephen Cory, Reviving the Islamic Caliphate in Early Modern Morocco (Abingdon: Routledge, 2016).

13 P. G. Rogers, A History of Anglo-Moroccan Relations to 1900 (London: Foreign and Commonwealth Office, [1977(?)]), pp. 22-24.

14 'Lettre de George Thomas à Robert Cecil', 30 October 1603, and 'Requête de Thomas Pate à Jacques Irr', [late 1603], in Les Sources inédites de l'histoire du Maroc. Prémiere sérieDynastie saadienne: Archives et bibliothèques d'Angleterre, ed. by Henry de Castries, Pierre de Cenival, and Philippe de Cossé Brissac, 3 vols (Paris: Ernest Leroux/Paul Geuthner, 1918-35), II (1925), pp. 229-35, 236-39. Hereafter, this series has been abbreviated to SIHMA. 
of existing trading privileges given by his predecessors. With this concession Harrison returned to London in April 1611. ${ }^{15}$

Immediately upon his arrival in Morocco, Harrison had made note of a report of 'pyrats' operating out of Mehdya, also on the Atlantic coast. The concern at the time was not the effect of their activity on English vessels, rather the fact that the pirates were selling captured goods at discounted prices, undercutting European merchants. ${ }^{16}$ But it was the issue of the capture and enslavement of Englishmen by the 'Sallee Rovers' that was the reason for Harrison's next mission to Zaydān. He was again dispatched with letters from the king, and finally arrived in Zaydān's camp in November 1614. Harrison was granted an audience with the sultan, who agreed to free any English captives held in his dominions. ${ }^{17} \mathrm{~A}$ possible Anglo-Dutch alliance against Spain may have also been discussed, and this could explain why Harrison was accompanied by the sultan's agent in the Netherlands, the Moroccan Jew Samuel Pallache. ${ }^{18}$ Zaydān provided Harrison with a letter to James in which he reaffirmed his friendship with England, and Harrison was also requested to personally deliver a letter to the States-General of the United Provinces. He returned to Morocco around June the following year to deliver the responses. ${ }^{19}$ Harrison was again sent to Morocco by the king in early 1616 to arrange the release of his subjects, as previously agreed, but had still not received a response from the sultan when he departed almost sixteen months later without seemingly having even disembarked. It is unclear whether Zaydān's failure to receive Harrison or establish any contact with him at this time was an unintentional snub, or, in fact, a sign of a more significant change in Zaydān's disposition toward England, as asserted later by Harrison. ${ }^{20}$

Whatever the reason, the incident led to a hiatus in formal diplomatic relations which lasted for some seven years, and only ended when an English monarch once again sought the assistance of a Moroccan ruler against Spain, as

15 'Lettre de John Harrison à Salisbury', 10 June 1610, and 'Lettre de John Harrison à Salisbury', 14 October 1610, in SIHMA, II, 449-50, 452-54; Rogers, History of Anglo-Moroccan Relations, p. 24.

16 'Lettre de John Harrison à Salisbury', 10 June 1610, in SIHMA, II, 450.

17 'Relation de John Harrison', [end of 1627], in SIHMA, III (1936), p. 67; Rogers, History of Anglo-Moroccan Relations, pp. 24-25.

18 Matar, 'Harrison, John'. Mercedes García-Arenal and Gerard Wiegers identify several interactions between Harrison and Pallache which occurred between 1610 and 1614 in A Man of Three Worlds: Samuel Pallache, a Moroccan Jew in Catholic and Protestant Europe, trans. by M. Beagles (Baltimore: Johns Hopkins University Press, 2003), pp. 75, 85, 86, 88, 91. On attempts by Moriscos, with the aid of Pallache, to engineer an alliance with European powers against Spain, see Mercedes García-Arenal, 'The Moriscos in Morocco: From Granadan Emigration to the Hornacheros of Salé', in The Expulsion of the Moriscos from Spain:A Mediterranean Diaspora, ed. by Mercedes García-Arenal and Gerard M. Weigers (Leiden: Brill, 2014), pp. 286328 (pp. 312-13).

19 SIHMA, III, 67-68; Rogers, History of Anglo-Moroccan Relations, p. 25.

20 'Lettre de Francis Cottington à John Coke', 31 March 1618, and 'Lettre de John Harrison à Moulay Zidân', Tétouan, [c. July 1625], in SIHMA, II, 509, 571; 'Relation de John Harrison', [end 1627], in SIHMA, III, 68-69. 
Elizabeth had, and to appease the concerns of his subjects about their kin held captive in Morocco. ${ }^{21}$ Nevertheless, the archival records for this period of official diplomatic quiescence reveal the strength of the underlying interest that Britons still had with Morocco: trade and commerce continued unabated, merchants and officials maintained a close eye on political developments and other happenings, negotiations on the release of captives were undertaken, and attempts were made to nurture relations with local rulers within a splintered polity. ${ }^{22}$

\section{Seeking Allies and Converts, 1625-27}

In 1625 James I died and was succeeded by his son, Charles I. James had never embraced relations with Morocco beyond the necessity for prosaic diplomacy concerning the release of captives or the commercial interests of his subjects. The factors which had helped drive and define what came to be seen as a golden age of Anglo-Moroccan diplomatic relations during the latter part of the sixteenth century were no longer extant. Aside from the death of the architects of the entente, the threat to England from Spain had diminished with the signing of the Peace of London in 1604. Furthermore, with al-Mansūr's passing, Morocco had descended into political and social anarchy, making it difficult for merchants and officials alike to negotiate an everchanging landscape of sovereignty across the country, as well as disrupting traditional trading patterns. But, conversely, the unrest encouraged illicit trade by English merchants with the warring parties, particularly in weapons, which became a new source of diplomatic tension.

Preparations for the resumption of hostilities with Spain in 1625 motivated the new English king to attempt a rapprochement with his country's past ally, and he dispatched his father's former envoy, John Harrison. In a personal letter to Zaydān, Charles reminded the sultan of the 'greate amyty and corespondacy' which had existed between Elizabeth and al-Mansūr, and expressed his desire that it 'continewe for the good of the subjects of both our dominions, and other reasons he [Harrison] can more at large informe yow'. ${ }^{23}$ Harrison subsequently arrived in Tétouan on Morocco's Mediterranean coast in June that same year on his fifth mission. But before examining the events of this mission it is necessary to understand more about the nature of the man who had been charged with this important task.

While they were undoubtedly important to him, Harrison's interests in North Africa were clearly more than just a desire to serve his country by fulfilling his commission, and to achieve personal financial gain and improve his status. His writings reveal him to be a deeply religious man, staunchly anti-Catholic, and

21 'Lettre de Charles Ir à Moulay Zidân', [27 March-1 June 1625], and 'Lettre de John Harrison à Moulay Zidân', Tétouan, [13 June-30 July 1625], in SIHMA, II, 565-66, 571-72.

22 See, for example, the correspondence dealing with these issues in SIHMA, II, 510-64, passim.

23 'Lettre de Charles I ${ }^{\text {er }}$ à Moulay Zidân', [27 March-1 June 1625], in SIHMA, II, 566. 
possessed of 'a deep evangelical zeal' ${ }^{24}$ The way in which the interarticulation of these elements of Harrison's character and motivations helped shaped his thinking about Morocco is well demonstrated in a pamphlet he published in 1613, The New Prophetical King of Barbary. The pamphlet is purported to reproduce correspondence from an English merchant residing in Morocco concerning the latest political developments there. Harrison's correspondent, 'R. S.', recounts the success of a Sufi mystic or marabout, Abu Mahalli (c. 1560-1613), ${ }^{25}$ in a popular uprising against Mawlay Zaydān. The majority of the account is particularly noteworthy for R. S.'s support for, and admiration of, the rebel leader. ${ }^{26}$

R. S. records that Abu Mahalli announced that he came to make peace, having been sent by God to challenge the ruling dynasty, 'to stablish their Prophets religion $[. .$.$] and recover those parts of Christendome the king of Spaine holds$ from them [...] and tels his people they shall yet see great wonders come to passe'. One such wonder would be the appearance of a bridge across the Strait of Gibraltar by which his followers would invade Spain, Italy, and France, and having achieved this he would reign for forty years until the coming of Christ and the final judgement; but, he insisted, 'for England, Flanders or other parts they have not to doe, they will have friendship with us' ${ }^{27} \mathrm{R}$. S. recounts all this without any hint of alarm or scepticism. But the treatment of subsequent details of the marabout's life and achievements becomes distinctly ambivalent. ${ }^{28}$ By the end of the account the tone changes once again, from ambivalence to outright hostility, with R. S. purporting to state:

For my owne part I am perswaded, they be delusions of the divell done by witchcraft, and permitted by the Lord, to seduce them to further error. God deliver us Christians well from among them, and grant us the use, and true knowledge of his holy word preached in Christian countries which here we want. ${ }^{29}$

During the course of the letter Abu Mahalli has been transformed from a saviour of the country, and a potential ally of Protestant nations, to an agent of the devil. The combined text is inherently contradictory-Abu Mahalli is both lauded

24 Matar, 'Harrison, John'.

25 The French term marabout, derived from the Arabic murabit, is commonly used to designate a Muslim mystic. However, in North Africa the word may also have an association with a holy man's involvement in warfare. See Julian Baldick, Mystical Islam: An Introduction to Sufism (London: Tauris, 2012), p. 129. While Abu Mahalli is often referred to as a marabout, Baldick notes that he was, in fact, 'a student of many different disciplines'. Abu Mahalli is a fascinating character and much has been written about him and the influential role played by marabouts in North African political history more generally, but both subjects are outside the scope of this article.

26 See, for example, R. S., The New Prophetical King of Barbary or the Last Newes from Thence in a Letter Written of Late from a Merchant There, to a Gentl. Not Long Since Imployed into that Countrie from His Maiestie, ed. by John Harrison (London, 1613), sigs B3 ${ }^{\mathrm{v}}, \mathrm{B}[4]^{\mathrm{v}}-\mathrm{C}^{\mathrm{r}}$.

27 R. S., New Prophetical King, sig. B3 ${ }^{\mathrm{r}-\mathrm{v}}$.

28 R. S., New Prophetical King, sigs C $-\mathrm{C}^{\mathrm{r}}$.

29 R. S., New Prophetical King, sig. C[3] $]^{\mathrm{r}}$ (my emphasis). 
and demonized - so much so that the exercise of editorial licence by Harrison appears to be the only plausible explanation..$^{30}$ At the very least the account, as with others from this period, is marked by deep ambivalence, of conflicting perceptions concerning the Indigenous peoples, particularly their leaders. ${ }^{31}$

The pamphlet as a whole appears to be intended to serve as an apocalyptic and cautionary tale, warning of the dangers of false prophets (including the Pope), ${ }^{32}$ highlighting the risk of civil conflict arising from pride and self-interest, ${ }^{33}$ and defending the doctrine of the divine right of kings, "whether Christian, or heathen' ${ }^{34}$ But Harrison also teasingly remarks in the epilogue that the civil unrest 'may serve for another use: a finall use of all, either that hath passed, or may hereafter fall out' ${ }^{35}$ It is a cryptic statement, but he appears to be implying that an opportunity may arise as a result of the disorder. It is possible that Harrison was conveying a millenarian expectation, but more likely he was alluding to the more immediate possibility of political and evangelical intervention in Morocco, proposals for which he would later develop and promote. However, the timing of the publication and its nature indicates that Harrison had a motivation beyond patriotic and religious service. In the previous year he had lost his patron, Prince Henry, and the pamphlet appears to have been a means by which he sought to promote himself as a man of true Protestant conviction, having significant knowledge of, and experience in, Morocco, and possessing a mysterious, yet beguiling, plan.

Harrison's lack of gainful employment at the time again appears to have been a motivation behind his publication of another text which also appeared the same year, the treatise The Messiah Alreadie Come. ${ }^{36}$ It was dedicated to Maurice, Prince of Orange, from whom Harrison undoubtedly sought favour. ${ }^{37}$ But it is an

30 Gary K. Waite compares and contrasts this account and two Dutch pamphlets which also deal with the conflict between Mawlay Zaydān and Abu Mahalli during this time. However, Waite overlooks the inherent dissonance in the English text. See Waite, 'Reimagining Religious Identity: The Moor in Dutch and English Pamphlets, 1550-1620', Renaissance Quarterly, 66 (2013), 1250-95 (pp. 1278-85).

31 Kenneth Parker also makes this observation in "Reading "Barbary" in Early Modern England, 1550-1685', The Seventeenth Century, 19 (2004), 87-115 (p. 101).

32 R. S., New Prophetical King, sig. A[4] $]^{\mathrm{rv}}$.

33 'Non unquam tulit documenta, fors majora quam fragili loco starent superbi' ('Never did fortune give larger proofs on what shaky ground stand the proud' (my translation)). See epilogue in R. S., New Prophetical King.

34 Preface in R. S., New Prophetical King.

35 Epilogue in R. S., New Prophetical King.

36 John Harrison, The Messiah Alreadie Come. Or Proofs of Christianitie, Both Out of the Scriptures, and Auncient Rabbins, to Convince the Jewes, of their Palpable, and More then Miserable Blindnes (if More May Be) for their Long, Vayne, and Endles Expectation of their Messiah (as They Dreame) Yet For to Come (Amsterdam, 1613). A second edition was printed in Amsterdam in 1619, and a third edition appeared in London in 1656, entitled $A$ Vindication of the Holy Scriptures. Or the Manifestation of Jesus Christ. The True Messiah Already Come.

37 Refer to the last paragraph of the dedication. To ensure that was there no doubt about the reasons he was giving Maurice the honour, nor about his current circumstances, the 
altogether different document to The New Prophetical King; written by Harrison while he was residing in Morocco in 1610, it provides insight into his attitudes to Moroccan society, and his theological beliefs. The treatise reveals Harrison as a millenarian Protestant whose convictions were also heavily influenced by a contemporary phenomenon in which a more positive interest in the Jewish people and their culture and history was promoted - a general disposition that has been termed philo-semitism, which developed in England from the early seventeenth century. ${ }^{38}$ It is a detailed polemic intended to convince Jews of the truth of Christianity, and encourage them to convert, not simply to save their souls, but, together with the destruction of the Catholic Church, as a precondition for the arrival of the Apocalypse and the Second Coming. ${ }^{39}$ The identification of Harrison as a millenarian is reinforced by his continued interest in the dispossessed elector of the Palatinate, Frederick V (1596-1632) and his wife, whose cause to regain the lands he lost soon after the commencement of the Thirty Years War became the focus of various portentous ideas among Protestants with chiliastic beliefs, such as Harrison. ${ }^{40}$

During his mission to Morocco in 1610 Harrison spent a period of almost six months in Safi on the Atlantic coast, during which time he was befriended by a local rabbi, and a further three and a half months living among the Jewish community in Marrakesh. ${ }^{41}$ While in The New Prophetical King Harrison does not express any views about Arab or Berber Moroccans, beyond criticizing them for their gullibility for having been deceived by 'idle and superstitious vanities' ${ }^{42}$ in his treatise he openly reveals his feelings and perceptions about Moroccan Jews. He notes that while in Safi, the rabbi helped better acquaint him with Hebrew, and Harrison found him to be 'of grave, and sober cariage, and pleasant otherwise', and was glad to have his company during what he describes as 'that tedious

dedication was also translated into Dutch while the remainder of the document is only rendered in English.

38 Ronald H. Fritze, 'Jews in England', in Historical Dictionary of Stuart England, 16031689, ed. by Ronald H. Fritze and William B. Robison (Westport, CT: Greenwood Press, 1996), pp. 269-70. For a more detailed account of the development of philo-semitism in England, see David S. Katz, Philo-Semitism and the Readmission of the Jews to England, 1603-1655 (Oxford: Clarendon Press, 1982).

39 Harrison acknowledges that much of the content is not original, but 'borrowed' from another text, 'The Christian Directorie or Resolution', by which he undoubtedly means Robert Persons's The Christian Directorie, Guiding Men to their Salvation, originally entitled The First Booke of the Christian Exercise, Appertayning to Resolution, published in 1582. See Harrison, The Messiah Alreadie Come, sig. A2v . On the importance of the Jews to English millenarian thought, see Katz, Philo-Semitism, ch. 3.

40 John Reeve, 'Sir Dudley Carleton and Sir Thomas Roe: English Servants of the Queen of Bohemia and the Protestant International during the Thirty Years War', Parergon, 32.3 (2015), 151-81 (p. 166). Frederick acquired the sobriquet 'the Winter King' among his detractors as a result of his brief reign as King of Bohemia between 1619 and 1620.

41 Harrison, Messiah Alreadie Come, pp. 61-62.

42 R. S., New Prophetical King, sig. A[4]. 
time'. ${ }^{43}$ In Marrakesh he 'grewe familiarly acquainted' with various members of the local Jewish community, attending wedding ceremonies and 'solemne feasts', and was introduced to their 'dainties' (food) which he 'tooke very kindly, and ever since have studied' ${ }^{44}$ It is unclear whether his experiences in Morocco in 1610 encouraged Harrison to embrace philo-semitism or he had already done so, but they undoubtedly contributed to his convictions. His account of that time shows him to be a person who was genuinely interested in Jewish culture, and who possessed a level of concern about the situation of Jews, particularly that of 'the forlorne, and distressed Jewes in Barbarie', ${ }^{45}$ that went beyond the requirements of pure eschatological belief. All these beliefs and attitudes which are reflected in his earlier writing conditioned to some extent or other Harrison's subsequent thinking concerning Morocco and its people.

The exact purposes for which Harrison had been sent to treat with the sultan in 1625 are not clearly stated in the letters provided to him by Charles I and Harrison. Charles's earlier letter indicates that captives remained a source of grievance, and Harrison confirms that he had been charged to negotiate their release. ${ }^{46}$ But the king also referred to 'other reasons' that would be expounded on by Harrison. While Harrison did not elaborate in detail, it is evident that Charles was seeking assistance from Zaydān in his war with Spain. In a letter to Zaydān written shortly after his arrival, Harrison reminds the sultan that he had requested Harrison to advise him 'if there were any lykelyhood of wars' and, if so, he would give assistance to the English. He goes on to insist that 'now is the tyme or neaver' for both parties 'to right themselves against theire enimies' ${ }^{47}$

However, in a later report to Charles, Harrison reveals that the mission had been initiated, at Harrison's suggestion, to 'sound the affectiones and dispositions of that people [Moroccans], and especiallie the Moriscoes or Andaluzes banished out of Spaine' who, as a result of their hatred for the Spanish and knowledge of that country, may be useful in many ways, including in the provision of supplies and other necessities for the English navy. ${ }^{48}$ But it is unclear that when Harrison embarked on the mission he possessed a defined plan for how Morocco could be engaged in prosecution of the war. ${ }^{49}$ A plan would emerge, shaped by Harrison's subsequent experiences in the country, and detailed in a proposal that he sent to the commander of an English fleet which he had been advised would visit Morocco shortly after his arrival.

43 Harrison, The Messiah Alreadie Come, p. 61.

44 Harrison, The Messiah Alreadie Come, p. 62.

45 Harrison, The Messiah Alreadie Come, p. 61.

46 'Lettre de John Harrison au commandant de la flotte britannique', 20 July 1625, in SIHMA, II, 575.

47 'Lettre de John Harrison à Moulay Zidân', [13 June-30 July 1625], in SIHMA, II, 572.

48 'Relation de John Harrison', 1 September 1627, in SIHMA, III, 30.

49 Cf. Matar, 'Harrison, John'. 
Harrison had intended to travel first to Salé, 'there to have understood the state of the countrie', and then to meet with the sultan. ${ }^{50}$ But he was convinced by the muqaddams (leaders) of Tétouan that due to the conflict within the country it was far too dangerous to do so by land, and was otherwise dissuaded by them from meeting with Zaydān. His hosts proceeded to impugn Zaydān's character and power before revealing that they no longer paid allegiance to him, and set about attempting to take advantage of the good fortune of having the English king's representative in their midst. ${ }^{51}$ According to Harrison, they offered him, 'freelie, and of their owne accord', in excess of ten thousand men to assist the English to take the Spanish enclave at Ceuta, 'or any other place near'. All that they requested in return was a supply of gunpowder and the repair of some ordnance. ${ }^{52}$

Harrison was very much enamoured by this proposal and was clearly convinced that there was not only widespread popular support for war with Spain, but also a 'generall disposicion and inclination both towards our nation, and even to Christian religion' ${ }^{53} \mathrm{He}$ was not necessarily misguided in these conclusions. As Mercedes García-Arenal points out, the Moriscos not only considered the English and Dutch as potential allies in their long-held plans to reconquer their former lands in Spain, but also found the form of Christianity which they professed easier to identify with than Catholicism. ${ }^{54}$ Inspired by his positive reception and 'to blow the fire already kindled', ${ }^{55}$ Harrison drafted two public letters to express England's amity with 'Moores, Turkes, Jewes and others', and highlight their common cause against the Catholic powers. ${ }^{56}$ The events in Tétouan also gave him reason to reflect on his mission and consider new possibilities. In his report to the commander of the English fleet, Harrison outlines an ambitious plan. He explains that with the help of the people of Tétouan, Ceuta could be taken and become an entrepôt for English trade. Jews and Moriscos, most of whome were 'alreadie Christian in heart', and even Moors, would flock to the enclave, providing it with both men and other supplies. He further suggested dispossessing Spain of Gibraltar and 'Mamora' (Mehdya) to provide England with not only control of

50 'Lettre de John Harrison au commandant', in SIHMA, II, 580.

51 'Lettre de John Harrison au commandant', in SIHMA, II, 575-76, 581.

52 'Lettre de John Harrison au commandant', in SIHMA, II, 576. In this account Harrison implies that the offer of the ten thousand men was the initiative of the muqaddams, but in a much later account he indicates that this had been his aim from the beginning. See 'Mémoire de John Harrison', 15 July 1631, in SIHMA, III, 145. It is quite possible that Harrison wished his compatriots to believe it was a spontaneous proposition to evidence local support for it.

53 'Lettre de John Harrison au commandant', in SIHMA, II, 578.

54 García-Arenal, 'The Moriscos in Morocco', p. 314. In fact, García-Arenal also notes that following their arrival in Morocco, many Moriscos proclaimed to be Catholics and were treated as apostates. See 'The Moriscos in Morocco', pp. 317-18.

55 'Lettre de John Harrison au commandant', in SIHMA, II, 578.

56 'Lettre de John Harrison aux Maures', 27 June 1625, in SIHMA, II, 567-68. 
the Strait, but also a base from which to attack Spanish shipping and to disrupt supplies to Spain's other possessions in Morocco. ${ }^{57}$

At least partly, what Harrison proposed was a strategy to help prosecute the war with Spain. But like an earlier envoy, the commercial agent Henry Roberts who had represented Elizabeth I in al-Mansūr's court over two decades earlier, Harrison was also offering a means to further England's religious, political, and commercial interests in Morocco itself. However, unlike Roberts, Harrison was not recommending that this be achieved through the conquest of the country, but rather by nurturing the continuation of political instability, and the development of relationships with all parties which were advantageous to England's interests. ${ }^{58}$ While Roberts had been seemingly motivated by impecuniousness and a desire to curry the king's favour, Harrison was inspired by evangelical zeal and a belief that Moriscos and Jews were crypto-Christians awaiting release from Muslim thraldom. Harrison's religious myopia even allowed him to envisage a general flight of people from tyranny in Spain, Portugal, and Morocco following the execution of his plan. ${ }^{59}$

In this respect the report appears to indicate a significant change in his attitude toward Zaydān, and perhaps Morocco's traditional political leadership more generally, in response to what he had observed or been told, which may have helped inform his plan. Whereas Harrison had previously defended Zaydān as the divinely appointed ruler of Morocco, his report reflects disillusionment with the sultan. Concerned with what he had heard about the sultan's usage of his people and Christian captives, and his complicity in corsairing, 'even to the English Channell', ${ }^{60}$ Harrison began to question Zaydān's legitimacy, allowing him to conceive of usurping his authority in the interests of England's Protestant cause. It was a bold but naive plan, and, as with such proposals in the past, it came to nothing, as was also the case when Harrison presented a similar proposal to Charles I some two years later. ${ }^{61}$ These proposals were no more than fantasies based on an overestimation of English military power, and either a flawed understanding of Moroccan motivations and aspirations, or an overriding desire to believe otherwise. Yet while they may not represent a milestone in the evolution of English colonial adventurism, they certainly indicate a marked development in Harrison's thinking.

Harrison left Tétouan and travelled to Salé in early 1626 where he met with Muhammad al-'Ayāsh̄̄, the charismatic leader of a local Arab tribe and marabout who had commenced a jihad against the Spanish and subsequently rebelled against

57 'Lettre de John Harrison au commandant', in SIHMA, II, 579-80.

58 'Lettre de John Harrison au commandant', in SIHMA, II, 580. On Roberts, see 'Mémoire de Henry Roberts à Jacques I'r', [3 April 1603], in SIHMA, II, 222-28.

59 'Lettre de John Harrison au commandant', in SIHMA, II, 581. Cf. Matar, Britain and Barbary, pp. 42-43.

60 'Lettre de John Harrison au commandant', in SIHMA, II, p. 580.

61 'Relation de John Harrison', 1 September 1627, in SIHMA, III, 53-54, 56. See also Matar, Britain and Barbary, p. 43. 


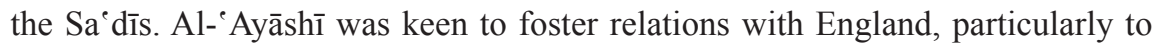
obtain assistance to take Mehdya from the Spanish. Harrison also concluded an agreement with the Moriscos to provide them with armaments and ammunition in exchange for the release of captives, before embarking for England in May of that year. ${ }^{62}$

\section{Picking Sides, Questions of Legitimacy, and Friendships, 1627-30}

It was not long before Harrison returned, arriving in January 1627 with instructions to treat with the 'King, Princes, Governors and Commanders of the parts of Barbary' for both the redemption of captives and to establish relations for 'our common utillety and safety'. ${ }^{63}$ Charles does not appear to have been concerned at the time with whom Harrison treated, so it is unsurprising that he first contacted the Moriscos of Salé with whom he had developed a close relationship. It was around this time that the Salétins withdrew their allegiance from the $\mathrm{Sa}^{\mathrm{e}} \mathrm{d} \overline{\mathrm{s}}$ and formally announced their independence. Notwithstanding this act of rebellion, Harrison negotiated an agreement with the town's leaders which guaranteed freedom of trade with Salé and protection of English vessels, and provided for the release of Britons held captive there. ${ }^{64}$ Despite receiving an order from Zaydān soon after the agent's arrival that Harrison be sent to him, the Salétins refused to release him, and Harrison made no effort to meet with the sultan before embarking for England in late May $1627 .{ }^{65}$

As well as returning with almost two hundred emancipated Britons, Harrison also brought with him a draft treaty which may have been of great benefit to England. However, Charles declined to endorse the treaty on the advice of the Court of Admiralty. In the court's view, the Moriscos were not suitable treaty partners as they were considered to be both pirates and rebels. ${ }^{66}$ Without their maritime activities being sanctioned by a recognized sovereign power, the Moriscos of Salé could not even claim the questionably superior status of corsairs. ${ }^{67}$ Nevertheless, not wishing to antagonize the Salétins, the king, in a carefully worded letter, did

62 'Lettre de Sidi Mohammed el-'Ayyachi a Charles I ${ }^{\text {er', }} 7$ May 1627, and 'Relation de John Harrison', 1 September 1627, in SIHMA, III, 23, 32-34.

63 'Lettre de commission pour John Harrison', 5 December 1626, in SIHMA, III, 12.

64 'Projet de traité entre Salé [Rabat] et 1'Angleterre', 30 April 1627, in SIHMA, III, $16-20$.

65 'Relation de John Harrison', 1 September 1627, in SIHMA, III, 39-40, 48.

66 Rogers, History of Anglo-Moroccan Relations, p. 27; Kenneth R. Andrews, Ships, Money and Politics: Seafaring and Naval Enterprise in the Reign of Charles I (Cambridge: Cambridge University Press, 1991), p. 169. The House of Lords had earlier agreed that a treaty was the best means to achieve the release of the captives and that the king be advised to this affect, but members had assumed that any treaty would be with the sultan. See 'House of Lords Journal Volume 3: 19 April 1626', in Journal of the House of Lords, 64 vols (London, 17671830), III: 1620-1628, p. 564, British History Online <http://www.british-history.ac.uk/lords-jrnl/ vol3/pp562-565> [accessed 15 July 2016].

67 On the legal status of corsairs and prize law in the Mediterranean in the early modern period, see Stein, 'The Mediterranean in the English Empire of Trade', pp. 208-211. 
express his gratitude for the release of his subjects and for the promise of freedom of trade, and assured them that they would receive similarly favourable treatment from the English. ${ }^{6}$ While Charles did not intend to formally acknowledge the treaty, he clearly desired the terms which had been negotiated; it was to be a treaty in all respects but in name.

Harrison subsequently prepared a report for the king on his last two missions. But it is more than a simple account of events and observations; he uses it to undermine the legitimacy of Zaydān's rule and argues fervently in support of alliances with the Moriscos of Tétouan and Salé, and with Muhammad al-'Ayāshī. In doing so, the report also reveals more about Harrison's personal beliefs, and what effect his experiences in Morocco may have had on them. His disdain for Zaydān is obvious throughout the account. In Harrison's view, the sultan is not only a cruel tyrant, but the 'originall of all these evils' committed against Christians at Salé, ${ }^{69}$ the instigator of the enslavement of the king's subjects; ${ }^{70}$ and treacherous. ${ }^{71}$ Furthermore, he insinuates that Zaydān's hold on power is tenuous, ${ }^{72}$ he is regarded with suspicion by even his own men, and is in league with Spain. ${ }^{73}$ In contrast, he asserts al- Ayāshī was an enemy of Spain, and a friend of England, whose followers hold the king in 'great honour and love'. ${ }^{74}$ The Moriscos also hold the king in high regard, are grateful for the assistance he has provided to them, and offer their services to him. ${ }^{75}$ According to Harrison, the Moriscos possessed 'a verie great affection and inclination to our nation', as do many Arabs and Berbers. ${ }^{76} \mathrm{He}$ argues that this sentiment must be patiently nurtured. ${ }^{77} \mathrm{He}$ also questions whether they, in fact, should be regarded as rebels. If England was prepared to treat with Algiers, why should it not also do so with the Moriscos? And in any event, to whom should they be loyal when they were born Christians in Spain, banished and delivered 'into the hands of infidels', and now after establishing a 'Christian government' they profess their love for Charles and seek his protection. ${ }^{78}$ Overlooking the obvious difference in religion, Harrison questions whether in this respect they are any different to the Dutch Republic, which England was supporting. ${ }^{79}$

68 'Lettres de Charles Ier', 12 October 1627, in SIHMA, III, 58-59.

69 'Relation de John Harrison', 1 September 1627, in SIHMA, III, 42.

70 'Relation de John Harrison', 1 September 1627, in SIHMA, III, 33, 51.

71 'Relation de John Harrison', 1 September 1627, in SIHMA, III, 39-40. On Harrison's views regarding Zaydān and his rule, see also 'Relation de John Harrison', [end 1627], in SIHMA, III, 65-67.

72 'Relation de John Harrison', 1 September 1627, in SIHMA, III, 32, 36-37, 53.

73 'Relation de John Harrison', 1 September 1627, in SIHMA, III, 37.

74 'Relation de John Harrison', 1 September 1627, in SIHMA, III, 44.

75 'Relation de John Harrison', 1 September 1627, in SIHMA, III, 30-32, 38, 40-42.

76 'Relation de John Harrison', 1 September 1627, in SIHMA, III, 42.

77 'Relation de John Harrison', 1 September 1627, in SIHMA, III, 42-43.

78 'Relation de John Harrison', 1 September 1627, in SIHMA, III, 51-52 (p. 51).

79 'Relation de John Harrison', 1 September 1627, in SIHMA, III, 53. 
Harrison was attempting to convince the king to support the Moriscos in what he believed to be the furtherance of England's religious and secular interests, but in doing so he reveals genuine empathy for them. In particular, he laments their forced exodus from Spain, drawing parallels with those other people of Morocco with whom he also had affinity, the Jews:

Never the like desolation of people since that and of the Jewish nation [...] yea, more than lamentable [...] banished and betrayed, not only their bodies but their soules as a praie of the Devill into the hands of the Turkes and Moores, men, women and children [...] as a forlorne people scattered and dispersed like the Jewes to this daie. ${ }^{80}$

Harrison did not express any notable general prejudice against either Moroccan Arabs or Berbers, but it was the Moriscos, with their knowledge of Christianity and Europeanized culture, whom Harrison held in greatest favour, along with their similarly persecuted compatriots, the Jews.

The religion with which the majority of the people for whom he was eliciting support were affiliated warranted little critical attention from Harrison. His only explicit comments depict Islam as an oppressive system of idolatrous belief opposed to Christianity. ${ }^{81}$ Nevertheless, he comments favourably on marabouts, ${ }^{82}$ despite his apparent earlier editorial excoriation of Abu Mahalli, and, in particular, thought highly of al- 'Ayāshī, even though he was a committed mujahid. Harrison's relationship with al- 'Ayāshī is interesting; he obviously believed him to be a friend of England and useful for that reason, and, as with his relationship with the people of Tétouan and Salé, he went no further to question his motives. Instead Harrison seemed less concerned with understanding their religion than with finding signs that confirmed to him that the people of Morocco were potential allies, and, critically, ultimately religiously redeemable.

However, Harrison was eventually forced to acknowledge that the issue of religious difference did present a major impediment for any cooperative endeavours against the Spanish. Asked by al- 'Ayāshī to help enlist the support of a Dutch fleet for an attack against Mehdya, Harrison, in consultation with the Dutch admiral, had to concoct an excuse against its involvement. Despite the Spanish being 'of a contrarie profession and enimies', he did not believe it to be honourable 'to betraie them into the hands of infidels to be made slaves' ${ }^{83}$ He even anguished over wishing al- 'Ayāshī 'good successe' with his venture. ${ }^{84}$ Harrison clearly possessed a sense of fundamental Christian unity which overrode his anti-Catholicism. But this perhaps was not his only reservation. He also

80 'Relation de John Harrison', 1 September 1627, in SIHMA, III, 41. García-Arenal, 'The Moriscos in Morocco', p. 314, also remarks on the obvious sympathy which Harrison felt for the Moriscos.

81 'Relation de John Harrison', 1 September 1627, in SIHMA, III, 42, 52.

82 'Relation de John Harrison', 1 September 1627, in SIHMA, III, 32, 44, 46.

83 'Relation de John Harrison', 1 September 1627, in SIHMA, III, 44-45.

84 'Relation de John Harrison', 1 September 1627, in SIHMA, III, 45. 
demonstrates a general abhorrence of slavery irrespective of the nature of the victims. Misquoting Exodus 21, he states: 'Condemned by the law of God [...] manstealers and mansellers both alike, were they never so great enemies either to nation or religion; they [those enslaved] are the image of God by creation as the first, and so to be respected' ${ }^{85}$ While Harrison's attitudes and actions were clearly informed by religious conviction, they also appear to have been influenced by humanistic belief.

Harrison was clearly frustrated that his warnings about Zaydān and plans for fostering closer relations with Tétouan and Salé were falling on deaf ears at home. Toward the end of 1627 he wrote again to the king expressing criticism of the sultan. He questions Zaydān's integrity, and contrasts his behaviour with that of the Moriscos, and the outcomes which have been achieved by treating with them. Harrison even goes so far as advocating that a naval squadron be sent to the sultan's stronghold at Safi to coerce him to release captive Britons and to correct other alleged wrongs. Once again, Harrison asserts his belief in the imminent conversion of the Moriscos and emphasizes the strategic value of their ports for the supply of English vessels, particularly now that England was at war not only with Spain, but also with France. ${ }^{86}$

Notwithstanding Harrison's unwavering positive assessment of the Moriscos' disposition toward England, attacks on English vessels and captive taking by their corsairs continued to escalate. But the Moroccans in turn alleged that their ships were being preyed upon by English merchants and privateers, despite a proclamation by Charles prohibiting attacks on vessels from Algiers, Tunis, Tétouan, and Salé. ${ }^{87}$ In response, Harrison was again sent to Morocco to negotiate the release of captives and to re-establish peaceful relations. ${ }^{88}$ After a long delay due to impecuniousness resulting from his service to the king, Harrison arrived in Morocco in March 1630. He claims to have successfully allayed the concerns of the Salétins, confirmed their commitment to peace, and negotiated proposals for the improvement of trade. Harrison proposed to the king that he return with 'a mynister or twoo' to attend to the local merchants and proselytize among 'bothe Moores and Jewes, whose conversion we daylie expecte'. Before departing for England in late August he dispatched a letter to the new Sa dì sultan, Abd al-Malik II (r. 1627-31), who had assumed the throne following the death of his father, Mawlay Zaydān, but made no effort to meet with him, concerned with how he would be received, and regarding al-Malik even less favourably than his father. ${ }^{89}$

85 'Relation de John Harrison', 1 September 1627, in SIHMA, III, 36.

86 'Relation de John Harrison', [end 1627], in SIHMA, III, 63-72.

87 'Proclamation de Charles Ier', 22 October 1628, in SIHMA, III, 80-81. On these developments, see Andrews, Ships, Money and Politics, pp. 169-70.

88 'Lettres de commission pour John Harrison', 21 January 1629, and 'Relation de John Harrison', 28 September 1630, in SIHMA, III, 82-84, 111.

89 'Relation de John Harrison', 28 September 1630, in SIHMA, III, 111-12, 115-16. 
Harrison had not given up on his plans for expanding England's interests in the region, appending to his report a revised and more detailed proposal for the taking of Mehdya. ${ }^{90}$ In his view the action was justified because the place was held by the Spanish, who were 'enemies of both our nation and religion'. ${ }^{91}$ Furthermore, it would provide a good harbour for the resupply of vessels, a base from which to suppress the activities of both the Spanish and Muslim corsairs, and a trading centre for the whole area. Harrison envisaged a fortified plantation fully maintained by customs duties. He assured King Charles that the Moroccans 'earnestlie desire it', and that Jews and Moors would come seeking the king's protection from their own rulers and the civil unrest they had created. ${ }^{92}$ There was no risk, he states, that the Moroccans would retake it, 'for they desire it not to be in their owne hands', yet he still advised that, just to be sure, fifty percent of customs duties should be paid to Muhammad al- Ayāshī. ${ }^{93}$

Though that was not the limit of Harrison's vision. He suggested that the Salétins might also wish to join with the proposed English enclave, and enticed the king with a sign of their imminent conversion and a report of a supposedly secret silver mine nearby. ${ }^{94}$ Perhaps inspired by a French attempt to colonize 'Mogodore' (Essaouira) the previous year, he went on to propose that given the contempt which the sultan had shown towards the king and his subjects, an island off the coast of that city be taken from him, and another plantation established there on the same terms with the local leaders. From these two sites, Harrison conjectured, the English could monopolize trade across the country, and obtain the supplies necessary to attempt to take from Spain 'the Maderars' (Madeira), or possibly Gibraltar and Ceuta. ${ }^{95}$ These plans and expectations of popular support were not simply the products of Harrison's own devising: they had been actively nurtured by the leaders of Tétouan and Salé, al- 'Ayāshī, and even 'Captain John', the notorious Dutch pirate and later renegade corsair Jan Janszoon van Haarlem, perhaps better known as Murat Reis 'the Younger', the former president and grand admiral of the republic of Salé, ${ }^{96}$ with whom Harrison had developed a close relationship; and they continued to press him for a response from the king. Harrison concludes by suggesting that if Charles does not wish to take advantage of these opportunities, that he commission his brother-in-law, Frederick V, to work with the Dutch to do so. For Harrison, it was not solely an English cause, but

90 'Mémoire de John Harrison sur la Mamora', [28 September 1630], in SIHMA, III, 124-31.

91 'Mémoire de John Harrison sur la Mamora', in SIHMA, III, 125.

92 'Mémoire de John Harrison sur la Mamora', in SIHMA, III, 125-26.

93 'Mémoire de John Harrison sur la Mamora', in SIHMA, III, 128.

94 'Mémoire de John Harrison sur la Mamora', in SIHMA, III, 127-28.

95 'Relation de John Harrison', 28 September 1630, and 'Mémoire de John Harrison sur la Mamora', in SIHMA, III, 117-18, 130.

96 Among van Haarlem's exploits was the so called 'Sack of Baltimore' in June 1631, in which he captured 109 English inhabitants of the town of Baltimore, on the coast of County Cork in Ireland, and sold them into slavery in Algiers. 
more generally a Protestant one, and one he felt compelled to pursue one way or another. Whether the king provided a response to Harrison is unknown, but in any event the plan quickly became redundant with the signing of a treaty the following month which ended the war with Spain.

\section{Frustration and Despair, 1631-33}

Harrison returned to Morocco in September 1631 with instructions to meet with al-Malik's successor, his brother Mawlay al-Walid (r. 1631-36), and negotiate the release of captives. ${ }^{97} \mathrm{He}$ had also intended to visit Salé to reassure the town's people that action was being taken to address their grievances, but by this time the Salétins had lost faith with the English because of ongoing breaches of the peace, and became openly hostile toward them. ${ }^{98}$ Harrison was extremely disheartened by the situation. He was critical not only of the actions of his compatriots, but also the failure of the English government to act on his advice. He was concerned about the prospects for escalation of corsair activity, and, ultimately, the impact on the reputation of his nation and religion, and England's interests in Morocco. ${ }^{99}$ His concerns appear to have been heightened by both the concurrent efforts by the French to establish diplomatic relations with al-Walid, and the start of a new entente between the Salétins and the $\mathrm{Sa}^{\mathrm{C}}$ dis which he seems to have believed also threatened English trade and influence. ${ }^{100}$ Too 'afraid and ashamed to go ashoare' at Salé, Harrison proceeded to Marrakesh to meet with the new sultan. ${ }^{101}$

He already held high expectations for al-Walid, ${ }^{102}$ and the sultan indeed proved more receptive that his father and brother had been to normalizing relations with England and resolving the perennial issue of the release of captives. By February 1632 the two men had negotiated a draft treaty. ${ }^{103}$ The document principally concerns the rights of the English in the conduct of business in Morocco, and the obligations of the sultan and his subjects in this respect, although, interestingly, it does provide Moroccans with the right to both buy and sell goods in England. ${ }^{104}$ It is notable for the recourse in its construction to the 'favours and priviledges auntiently belonging to the English nation', ${ }^{105}$ with specific references made to those existing under the reign of Ahmad al-Mansūr, during the perceived golden

97 'Lettre de Charles I'r à Moulay El-Oualid', 19 July 1631, and 'Lettres de John Harrison à A. Carnwath', 29 September 1631, in SIHMA, III, 152, 161.

98 'Lettre de John Harrison à John Coke', 3 August 1631, and 'Lettres de John Harrison à A. Carnwarth', 29 September 1631, in SIHMA, III, 154, 160-62.

99 'Lettre de John Harrison à John Coke', 3 August 1631, and 'Lettres de John Harrison à A. Carnwarth', 5 October 1631, in SIHMA, III, 155, 164-66.

100 'Lettres de John Harrison à A. Carnwarth', 5 October 1631, in SIHMA, III, 163.

101 'Lettres de John Harrison à A. Carnwarth', 5 October 1631, in SIHMA, III, 165-66.

102 'Mémoire de John Harrison sur le Maroc', 15 July 1631, in SIHMA, III, 150.

103 'Projet de traité entre Moulay El-Oualid et Charles Ir', [6 November 1631-February 1632], in SIHMA, III, 174-78.

104 See Article 11.

105 'Projet de traité entre Moulay El-Oualid et Charles I'r', in SIHMA, III, 178. 
age of Anglo-Moroccan relations which was frequently evoked by parties on both sides during this period. While the treaty focused on English interests, it was conditional on acceptance of the sultan's own demands. As al-Walid explained in a letter to Charles, his subjects had been taken captive because English merchants had been trading in contraband arms with his enemies, and if the king wished to restore traditional relations he must put a stop to this trade. ${ }^{106}$ Harrison returned to England in May 1632 and presented the draft agreement to Charles, but the king, for reasons which were not revealed, failed to endorse it, and did not call on Harrison ever again.

Clearly unhappy with the outcome, in 1633 Harrison published an account of the reign of al-Malik II in which he detailed his 'cruel acts, and mad-pranks', none of which he had in fact witnessed himself, instead relying on the testimony of 'such both of our owne nation and others'. ${ }^{107}$ Harrison claims to have written it as a present for Frederick V's son and the nephew of Charles I, Charles Louis, the new Elector Palatine, and to assist him 'discerne betixt a blessed Christian government [...] and a cruel-tyrannous Mahometan government'. ${ }^{108}$ But this detail appears to simply have provided the context for its true purpose, which is revealed in a proposition and petition appended to the account. Expressing guilt and remorse for not having completed his mission of freeing the remaining Britons in Morocco, Harrison calls on Protestant rulers to unite and act to redeem all Christians held in North Africa, 'all those poore soules that are in miserie, both under the Turks and Moores'. 109

Harrison's utility as a diplomatic agent had perhaps come to an end due to the convergence of several factors which had less to do with his capabilities as an envoy than with his beliefs. Under James I there had been a move away from the more radically inclined, Calvinist predestinarianism ascribed to by Harrison. Furthermore, by the 1630s Spain was no longer seen as England's implacable enemy. In the interests of trade and the Exchequer, Charles I adopted a position of pro-Spanish neutrality; as a result, support for Protestant internationalism, of which opposition to Spain was a central component, was no longer a minority view, but also a potentially treasonable one. ${ }^{110}$ Moreover, while interest in philosemitism and millenarianism would continue to grow in England until the middle of the century, the promotion of Jews as being central to Christian eschatology remained a contentious issue. ${ }^{111}$ Therefore, Harrison's confessional and millenarian

106 'Lettre de Moulay el-Oualid à Charles I' ', 21 December 1631, in SIHMA, III, 170-73.

107 John Harrison, The Tragicall Life and Death of Muley Abdala Melek the Late King of Barbarie. With a Proposition, or Petition to all Christian Princes, Annexed thereunto: Written by a Gentleman Imployed into those Parts (Delph, 1633), p. 1. An extract from the pamphlet is provided in SIHMA, III, 191-206.

108 Dedication in Harrison, Tragicall Life and Death, sig. A2r.

109 Harrison, Tragicall Life and Death, sigs A2 ${ }^{\mathrm{v}}-\mathrm{A} 3^{\mathrm{r}}$ (dedication), pp. 20-24 (p. 22).

110 Reeve, 'Sir Dudley Carleton and Sir Thomas Roe', pp. 164, 175.

111 Katz, Philo-Semitism, pp. 1, 5, 95, 97. The decline in millenarianism and other mystical beliefs after this time can be seen as a sign of the subsidence of common anxiety which 
beliefs were, if not yet outmoded, potentially problematic, as too, possibly, were his increasingly strident views about the legitimacy of Morocco's professed rulers. Rather than customary authority, Harrison instead had invoked considerations of moral authority, popular sentiment, and territorial control to either support or challenge their dynastic legitimacy. It was an issue that would continue to vex the English in prosecuting their activities in Morocco over the following decades. Perhaps not coincidentally, it was also an issue that was beginning to assume great significance within England itself from around the same time as Parliament began to challenge the authority of the Stuarts, and as the country commenced its own descent into civil war. ${ }^{112}$

\section{Conclusion}

While the geopolitical contexts in which Harrison's missions to Morocco were undertaken are certainly important in understanding his thinking and actions, he in no way can be viewed simply as a servile mouthpiece for English foreign policy; his personal agency is clearly evident. Furthermore, while his encounters with the country may not have been epiphanic, leading to wholesale change in his underlying world view, Harrison's accounts and other writings demonstrate that his feelings, thoughts, and behaviour which they convey can only be fully understood with reference to the interplay between his existing religious persuasions and other personal beliefs, and the impact of his experiences in Morocco. This is certainly the case in relation to his views about dynastic legitimacy. The sociopolitical conditions which existed in the country in the early seventeenth century not only affected diplomatic and commercial relations, but through the process of personal acculturation they had the potential to deeply impact the perceptions and responses of Britons who sojourned there. Harrison's perceptions, particularly of Islam and Islamic government, were informed by what he observed and heard during his visits: bloody disputes over control of territory and resources, and propaganda bruited by partisan interests. He interpreted his personal interactions, events he experienced, and stories which he was told through the filter of his strong Protestant faith and millenarian beliefs. But he also manifested responses which reveal tensions arising from his adherence to more fundamental Christian and humanistic convictions, and, more generally, his disposition, ideas, and actions also reflect the deep anxieties commonly felt by Europeans in his particular age. ${ }^{113}$

Notably, religious and ethnological differences with the indigenes elicited little critical attention from Harrison, aside from his sympathetic observations

accompanied the tumultuous period of ideological and social change associated with what has been characterized as a 'general crisis' in Europe during the seventeenth century. See Theodore K. Rabb, The Struggle for Stability in Early Modern Europe (New York: Oxford University Press, 1975), pp. 51-52.

112 On contemporary thinking concerning monarchical legitimacy and associated developments leading up to the English Civil War, see Robert Zaller, The Discourse of Legitimacy in Early Modern England (Stanford: Stanford University Press, 2007), esp. ch. 7.

113 On these anxieties, see Rabb, Struggle for Stability, p. 4. 
about Jews and Moriscos, and his traditionally framed critique of Islam; in fact, he tended to direct any prejudice he held toward specific individuals rather than apply such feelings more generally. If anything, he appeared to be unconcerned by such differences, as demonstrated by the close relationships he developed in Morocco with a variety of people from different ethnic backgrounds. Like his compatriots operating elsewhere in the Mediterranean region, he manifested a significant degree of pragmatism and adaptability in his inter-cultural encounters. ${ }^{114}$

It has been argued by one scholar that the proposals developed by Harrison for the acquisition of enclaves in Morocco were the products of British imperial aspiration and represent a change in national ideology from a focus on trade to conquest of land and control of natural resources. ${ }^{115}$ However, rather than being considered evidence of a new imperial ideology Harrison's plans should be seen as the initiatives of a particular man operating within a specific set of circumstances. This is certainly borne out by the lack of enthusiasm with which they were received back in England. In any event, they can better be regarded as renderings of a more traditional understanding of a colony as 'the plantation of nucleated settlements within a foreign landscape', rather than of the 'exploitation and cultural domination' that are implicit in the much later concept of 'colonialism'. ${ }^{116}$

Renewed interest in the Mediterranean and the activity of Britons in the region in the early modern period is providing new insights into inter-cultural encounters and the impact that such engagement had on development of the British empire and British self-identity. In this article, I have attempted to examine the effect of acculturation on one early modern Briton to demonstrate the utility of attention to these processes in better understanding the responses of his compatriots arising from such encounters during a period of major expansion of England's trading networks and increasing contact with non-European peoples.

Attention to the influence of acculturation forces us to think beyond simplistic generalized notions of cause and effect and, rather, focus more precisely on the individual dynamics of encounter and their consequences. The insights into acculturation provided by cross-cultural psychology draw the historian's attention to the wider effects of cultural encounter; not just to its cognitive outcomes as reflected in acts of representation, but also to its sometimes more revealing affective and behavioural dimensions. They encourage the researcher to identify evidence of acculturation in narratives of encounter, and to consider their significance. Examination of these experiences through the lens of acculturation

114 On the general behaviour of Britons in the Mediterranean around this time, see, for example, Alison Games, The Web of Empire: English Cosmopolitans in an Age of Expansion, 1560-1660 (Oxford: Oxford University Press, 2009), pp. 47, 51-53, 74-79, 290, 297-98. Colley, Captives, pp. 133-34, refers to the necessary 'compromises and collusions' which were imposed on the British in operating in the Mediterranean.

115 See Matar, Britain and Barbary, pp. 42-43, 45, 134.

116 David Armitage, 'Literature and Empire', in The Oxford History of the British Empire, I: The Origins of Empire: British Overseas Enterprise to the Close of the Seventeenth Century, ed. by Nicholas Canny (1998), pp. 99-123 (p. 109). 
provides another perspective from which to read and analyse historical sources, to attempt to understand the meaning of encounter and identify the reasons for differences in the responses between people.

University of Tasmania 